\title{
Potentiation of in vitro apoptotic effects of $\delta$-tocotrienol and jerantinine A on human lung adenocarcinoma cells
}

\author{
Ibrahim Babangida Abubakar ${ }^{1,2}$, Hwei-San Loh $^{1,3^{*}} \mathbb{D}$ \\ ${ }^{1}$ School of Biosciences, Faculty of Science, The University of Nottingham Malaysia Campus, Jalan Broga 43500 Semenyih, Selangor Darul Ehsan, \\ Malaysia \\ ${ }^{2}$ Department of Biochemistry, Kebbi State University of Science and Technology, PMB 1144, Alero, Kebbi State, Nigeria \\ ${ }^{3}$ Biotechnology Research Centre, The University of Nottingham Malaysia Campus, Jalan Broga 43500 Semenyih, Selangor Darul Ehsan, Malaysia
}

\begin{tabular}{|c|c|}
\hline A R T I C LE I N F O & A B S T RACT \\
\hline $\begin{array}{l}\text { Article Type: } \\
\text { Short Communication }\end{array}$ & \multirow{11}{*}{$\begin{array}{l}\text { Introduction: The apoptotic effects of single-compound and combined sub-effective } \\
\text { concentrations of } \delta \text {-tocotrienol and jerantinine A on human lung adenocarcinoma (A549) } \\
\text { cells were investigated. } \\
\text { Methods: Assays including cell viability, histochemical and immunofluorescence staining } \\
\text { techniques, flow cytometry and enzyme activity were used. } \\
\text { Results: The combination of } \delta \text {-tocotrienol with jerantinine A at sub-effective concentrations } \\
\text { induced a synergistic effect and improved selective toxicity towards cancerous A549 cells } \\
\text { over normal lung fibroblast (MRC5) cells compared to the single-compound jerantinine. } \\
\text { Morphological features of apoptosis were evident on treated A549 cells. Combined sub- } \\
\text { effective concentrations of } \delta \text {-tocotrienol with jerantinine A induced a predominantly G2/M } \\
\text { cell cycle arrest and characterised by a disruption of microtubular networks mediated via } \\
\text { caspase } 8,9 \text { and } 3 \text { enzymatic activities. } \\
\text { Conclusion: These findings demonstrated improved potency in vitro and reduced dose- } \\
\text { related toxicity of jerantinine A to normal cells through prospective combined treatment } \\
\text { between low-concentration } \delta \text {-tocotrienol and jerantinine A for lung cancer. }\end{array}$} \\
\hline & \\
\hline Article History: & \\
\hline Received: 28 April 2019 & \\
\hline & \\
\hline Keywords: & \\
\hline$\delta$-Tocotrienol & \\
\hline Jerantinine A & \\
\hline Synergism & \\
\hline Apoptosis & \\
\hline Microtubules & \\
\hline
\end{tabular}

Implication for health policy/practice/research/medical education:

The combination of $\delta$-tocotrienol and jerantinine A at low dosage demonstrated improved apoptotic effect and reduced toxicity towards non-cancerous cells and as such could potentially serve as future chemotherapeutic regimen against lung cancer.

Please cite this paper as: Abubakar IB, Loh HS. Potentiation of in vitro apoptotic effects of $\delta$-tocotrienol and jerantinine A on human lung adenocarcinoma cells. J Herbmed Pharmacol. 2019;8(4):333-338. doi: 10.15171/jhp.2019.49.

\section{Introduction}

Lung cancer is one of the most common causes of cancer-related death. For instance, an estimate of over 200000 and 150000 new cases and death from lung cancer, respectively were reported in the United States in 2016 (1). Natural products have been continuously used as chemotherapeutic agents for cancer treatment. However, non-selective toxicity, drug resistance and metabolic degradation have limited the potency of a single chemotherapeutic agent. $\delta$-Tocotrienol is a dietary phytochemical that has demonstrated a good cytotoxic potency on several cancer cell lines (2). However, in vivo delivery of high dose tocotrienol overloads the transport protein resulting in metabolic degradation of tocotrienol, thereby limiting its potency (3). On the other hand, jerantinine $\mathrm{A}$ is an indole alkaloid isolated from the plant,
Tabernaemontana corymbosa of the Apocynaceae family which has been shown to inhibit various cancer cell types with particular emphasis on the vincristine-resistant nasopharyngeal cells (4). However, jerantinine A also induced similar toxic effects on non-cancerous MRC5 cells and hence jeopardizes its development study aiming for anticancer application in the future (5).

Combined therapy of phytochemicals has been suggested as an alternative to potentially overcome the abovementioned limitations. In fact, the potency of tocotrienols could be improved via the combined therapy even though a much lower concentration is used (6). Therefore, the present study investigated the cytotoxic and apoptotic effects of $\delta$-tocotrienol and jerantinine A which were combined at sub-effective concentrations aiming at improving the therapeutic potency and minimizing the 
non-selective toxicity towards the normal healthy cells.

\section{Materials and Methods}

Human cell lines and culture conditions

Human lung adenocarcinoma (A549) and normal lung fibroblast (MRC5) cells, purchased from ATCC, USA were used in this study. All cell lines were cultured and maintained in optimal conditions as previously described (7).

Neutral red uptake assay for evaluation of cell viability The viability of both A549 and MRC5 cells was determined based on the neutral red uptake assay described previously (8) in a 96-well plate format where A549 and MRC5 cells were pre-seeded at a density of $5 \times 10^{3}$ per well for 24 hours. These cells were independently treated with either $\delta$-tocotrienol (at $0-300 \mu \mathrm{g} / \mathrm{mL}$ concentrations) or jerantinine A (at $0-40 \mu \mathrm{g} / \mathrm{mL}$ concentrations) for 72 hours. Dimethyl sulfoxide (DMSO) was used as a vehicle control (negative) and vinblastine served as an anticancer drug control (positive). For combined treatment, $\delta$-tocotrienol (at $0-24 \mu \mathrm{g} / \mathrm{mL}$ concentrations) was combined with jerantinine $\mathrm{A}$ at its fixed $\mathrm{IC}_{20}$ concentration $(0.35 \mu \mathrm{g} / \mathrm{mL})$. The $\mathrm{IC}_{50}$ values of singlecompound and combined treatments were determined using the GraphPad Prism 5 software and presented as mean \pm SEM (standard error of mean) of triplicates completed in three independent experiments. Based on the combined treatment experiment, the combination index (CI) and dose reduction index (DRI) values were determined as previously described (9). The CI envisions the type of pharmacological interaction between the combined chemotherapeutic agents. CI values of $<1$, $>1$ or $=1$ indicate synergistic, antagonistic or additive pharmacological interactions, respectively (10). The DRI represents the fold reduction on potent concentrations of $\delta$-tocotrienol and jerantinine $\mathrm{A}$ used in the combined treatment over their individual $\mathrm{IC}_{50}$ values generated from the single-compound treatments.

Histochemical staining for examination of cellular morphologies

Each well of the 2-well chamber slides (SPL Life Sciences, Korea) was seeded with $5 \times 10^{3}$ A549 cells for 24 hours. The A549 cells were then individually incubated with respective $\mathrm{IC}_{50}$ concentration of $\delta$-tocotrienol, jerantinine $\mathrm{A}$ or vinblastine (positive control) for another 24 hours. The cells treated with plain media containing DMSO were served as the negative control. For combined treatment, A549 cells were incubated with a combination of $\delta$-tocotrienol $(2.77 \mu \mathrm{g} / \mathrm{mL})$ and $\mathrm{IC}_{20}$ concentration of jerantinine A $(0.35 \mu \mathrm{g} / \mathrm{mL})$. A protocol previously described for haematoxylin and eosin (H\&E) histochemical staining (7) was adopted and H\&E-stained cells were captured at 40X magnification under Nikon 80i microscope (Nikon, Japan).
Flow cytometry for cell cycle analysis

A549 cells $\left(1 \times 10^{6}\right)$ pre-seeded per well in 6-well plates (SPL Life Sciences, Korea) were incubated with similar concentrations of single-compound and combined treatments as stated in histochemical staining section for 24 and 48 hours. Cell cycle analysis was conducted using BD Accuri 6 Flow cytometer (BD Biosciences, USA) and based on the previously published procedures (8). Data were analysed using FCS express 5 research edition (De Novo Software, USA) and presented as mean \pm standard deviation $(\mathrm{SD})$ of three repeats.

Immunofluorescence staining for morphological detection of microtubules

A total of $5 \times 10^{3}$ A549 cells were seeded in 2-well chamber slides. Following 72-hour incubation with separate treatments consisting of single-compound $\mathrm{IC}_{50}$ and combined sub-effective concentrations (2.77 $\mu \mathrm{g} / \mathrm{mL}$ of $\delta$-tocotrienol and $0.35 \mu \mathrm{g} / \mathrm{mL}$ of jerantinine A) as well as positive and negative controls, A549 cells were stained using an immunofluorescence method as previously described (11). The slides were visualised at $40 \mathrm{X}$ magnification under Nikon eclipse $\mathrm{Ti}$ confocal microscope (Nikon, Japan).

Colorimetry for determination of caspase enzymatic activity

A549 cells pre-seeded at a density of $1 \times 10^{6}$ per dish in 90 $\mathrm{mm}$ petri dishes (SPL Life Sciences, Korea) for 24 hours, were separately treated with single-compound $\left(\mathrm{IC}_{50}\right)$ and combined sub-effective concentrations $(2.77 \mu \mathrm{g} / \mathrm{mL}$ of $\delta$-tocotrienol and $0.35 \mu \mathrm{g} / \mathrm{mL}$ of jerantinine A) at different time points (1-48 hours). Caspase 8,9 and 3 enzymatic activities were determined using Gene Tex colorimetric caspase 8 (GTX 85543), caspase 9 (GTX 85538) and caspase 3 (GTX 85558) kits according to manufacturer's instruction (Gene Tex, USA). The absorbance values for treated and control samples were measured at $405 \mathrm{~nm}$ and presented as mean \pm SD generated from triplicate experiments.

\section{Statistical analysis}

Statistical analysis of data was conducted using one-way ANOVA. Dunnett's test was used to assess for a significant difference between treated and untreated groups, as indicated at $P<0.001\left(^{* * *}\right), P<0.01(* *), P<0.05\left(^{*}\right)$ levels.

\section{Results}

Both $\delta$-tocotrienol and jerantinine $\mathrm{A}$ had growth inhibitory effects on A549 cells with $\mathrm{IC}_{50}$ values of 12.40 $\pm 1.09 \mu \mathrm{g} / \mathrm{mL}$ and $1.42 \pm 1.31 \mu \mathrm{g} / \mathrm{mL}$, respectively. Similar potent inhibitory effect was evident for the positive control vinblastine $\left(\mathrm{IC}_{50}=0.03 \pm 1.45 \mu \mathrm{g} / \mathrm{mL}\right)$ on $\mathrm{A} 549$ cells. However, jerantinine A induced similar growth inhibitory effect on normal MRC5 cells $(0.97 \pm 0.11 \mu \mathrm{g} /$ 
$\mathrm{mL}$ ). The combination of $\delta$-tocotrienol and jerantinine $A$ at sub-effective concentration induced synergistic effect $(C I=0.47)$ and caused a 4 -fold dose reduction on the concentrations of $\delta$-tocotrienol and jerantinine A compared to respective individual $\mathrm{IC}_{50}$ values (Table 1). Haematoxylin and eosin staining of individual and combined treatments showed morphological hallmarks of apoptotic cell death including cellular shrinkage and nuclear chromatin condensation on A549 cells incubated with $\mathrm{IC}_{50}$ concentrations of vinblastine, $\delta$-tocotrienol, jerantinine $\mathrm{A}$ and combined sub-effective concentrations of $\delta$-tocotrienol and jerantinine A. Formation of membrane blebs was particularly evident on cells incubated with $\mathrm{IC}_{50}$ of jerantinine A (Figure 1a).

As shown in Figure 1b, c, d, cell cycle analysis revealed the induction of G0/G1 and G2/M arrests on A549 cells by single-compound treatments of $\delta$-tocotrienol and jerantinine A, respectively after 24- and 48-hour incubation periods. On the other hand, the combined low concentrations of $\delta$-tocotrienol and jerantinine $\mathrm{A}$ induced G2/M arrest on A549 cells. Further investigation on the effects of single-compound and combined treatments on microtubules, was conducted. Indeed, immunofluorescence study revealed that jerantinine A inhibited or caused a disruption of microtubular network in A549 cells (Figure 2a). This was characterised by cell shrinkage and decrease in immunofluorescence intensity. Similar anti-microtubular effect was observed in A549 cells incubated with the microtubule-destabilising agent, vinblastine (positive control).

An evaluation of caspase enzymatic activity revealed that both single-compound $\mathrm{IC}_{50}$ and combined subeffective concentrations of $\delta$-tocotrienol with jerantinine A induced caspase 8, 9 and 3 enzymatic activities (Figure $2 \mathrm{~b}, \mathrm{c}, \mathrm{d})$. Interestingly, the combined treatment had boosted caspase 9 and 3 enzymatic activities, respectively up to 1.90 and 1.95 folds, which were considerably higher than those of single-compound $\mathrm{IC}_{50}$ of $\delta$-tocotrienol and jerantinine A.

\section{Discussion}

Combined treatment of phytochemicals has been suggested to improve potency and minimize non-selective toxicity. Herein, jerantinine A induced similar toxicity to A549 cells and normal MRC5 cells conforming to a previous report on its non-selective toxicity on normal cells (5). In contrast, unlike the single-compound treatments of $\delta$-tocotrienol and jerantinine $\mathrm{A}$, the combined treatment demonstrated more than 2-fold selective toxicity on A549 cells thereby minimizing toxicity on normal MRC5 cells. Indeed, the study herein conformed to previous suggestion that combined therapy could potentially minimize non-selective toxicity and improve potency of phytochemicals (6).

Further investigation using $\mathrm{H} \& \mathrm{E}$ staining technique revealed the manifestation of the morphological features of apoptosis on treated A549 cells. The cells undergoing apoptosis are single or cluster of cells that appear as circular or oval shaped mass with dark cytoplasm and dense purple nuclear chromatin upon staining with H\&E dyes (12). Similar morphological observation of these apoptotic features herein strongly indicates that single-compound and combined low concentrations of $\delta$-tocotrienol and jerantinine A induced apoptosis on A549 cells. An evaluation of cell cycle revealed that induction of G0/G1 and G2/M arrests A549 cells by single doses of $\delta$-tocotrienol and jerantinine $\mathrm{A}$, respectively, whereas, the combined treatment induced G2/M arrest. Microtubuletargeting agents have been shown to induce G2/M cell cycle arrest (13). Therefore, further investigation revealed that jerantinine A herein caused disruption of microtubules. This corroborated the previous mechanistic study that had demonstrated the potential anti-microtubular effect of jerantinine A (5). In contrast, untreated cells (vehicle control) and cells treated with $\mathrm{IC}_{50}$ of $\delta$-tocotrienol showed an intact $\alpha$-tubulin structure. Interestingly, combined low concentrations of $\delta$-tocotrienol and jerantinine A caused a considerable disruption of microtubules in A549 cells. This may be attributed solely to the $\mathrm{IC}_{20}$ of jerantinine $\mathrm{A}$ or could probably be potentiated by the presence of lowconcentration $\delta$-tocotrienol. To date, there is no study confirming the potentiation effect of a tocotrienol isomer on microtubules but this possibility cannot conclusively be ruled out. Nevertheless, the study has demonstrated an improved potency of $\delta$-tocotrienol thereby corroborating the previous combination studies on tocotrienols (3). Microtubule-targeting agents have been shown to induce apoptosis predominantly via the mitochondria pathway and caspase-independent pathway mediated via the activation of lysosomal cathepsin B (14).

Table 1. Combination index $(\mathrm{Cl})$ and dose reduction index $(\mathrm{DRI})$ values of combined sub-effective concentrations of $\delta$-tocotrienol $(0-24 \mu \mathrm{g} / \mathrm{mL})$ with jerantinine A at its fixed $\mathrm{IC}_{20}$ concentration $(0.35 \mu \mathrm{g} / \mathrm{mL})$ on $\mathrm{A} 549$ cells

\begin{tabular}{|c|c|c|c|c|c|}
\hline Cells & $\begin{array}{l}\text { Jerantinine } A(\mathrm{JA}, \mu \mathrm{g} / \mathrm{mL}) \text { [used at } \\
\left.\mathrm{IC}_{20}\right]\end{array}$ & $\begin{array}{l}\text { New concentration of } \delta \text {-tocotrienol }(\delta-\mathrm{T} 3, \mu \mathrm{g} / \mathrm{mL}) \\
\text { that induced } 50 \% \text { growth inhibition in combined } \\
\text { treatment }\end{array}$ & $\mathrm{Cl}$ & DRI & \\
\hline & (Mean \pm SEM) & (Mean \pm SEM) & $\delta-\mathrm{T} 3+\mathrm{JA}$ & $\delta$-T3 & JA \\
\hline A549 & $0.35 \pm 0.32$ & $2.77 \pm 1.09$ & 0.47 & 4.48 & 4.06 \\
\hline MRC5 & $0.35 \pm 0.32$ & $5.57 \pm 1.22$ & - & - & - \\
\hline
\end{tabular}

DRI represents the fold decrease in required potent concentration to induce $50 \%$ cell growth inhibition following a combined treatment. Pharmacological interaction between the combined treatment is reflected by either synergistic $(\mathrm{Cl}<1)$, antagonistic $(\mathrm{Cl}>1)$ or additive $(\mathrm{Cl}=1)$ effects. 
(a)

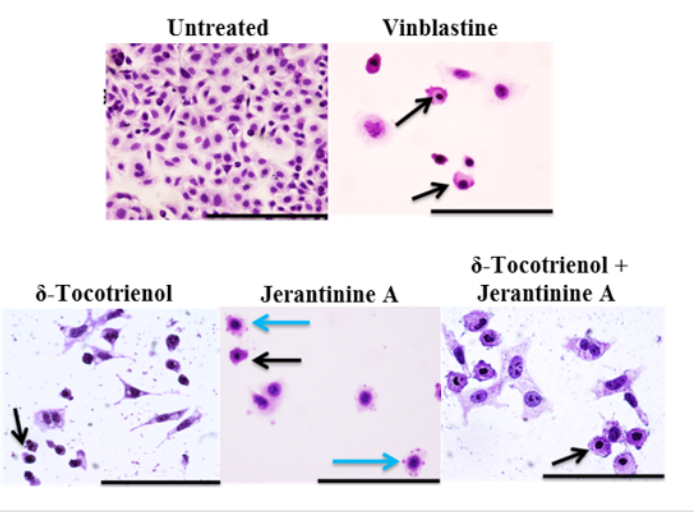

(b)
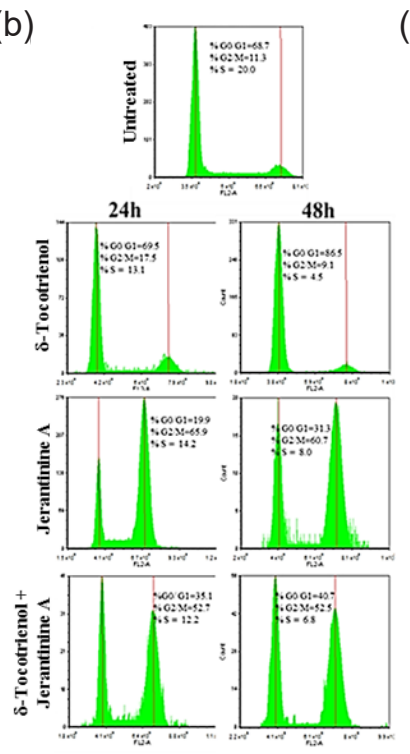

(c)

(d)

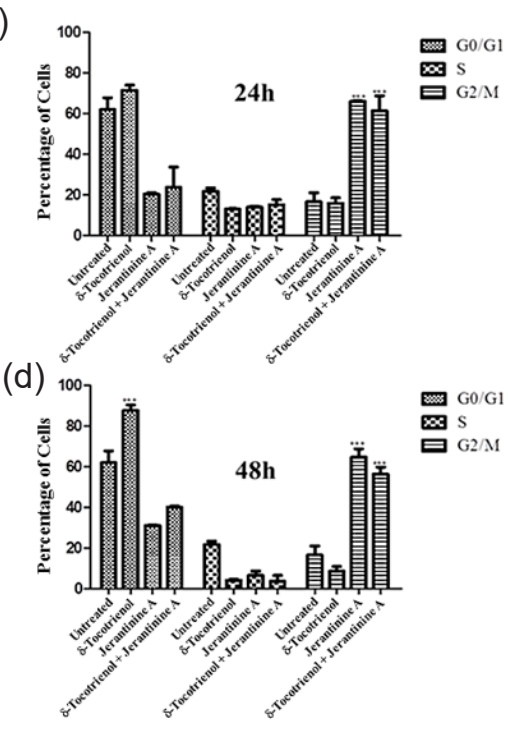

Figure 1. Evaluation of cellular morphologies and cycle arrests in A549 cells. (a) Microscopic observations on H\&E-stained A549 cells receiving the single-compound treatments with $\mathrm{IC}_{50}$ of $\delta$-tocotrienol, jerantinine $\mathrm{A}$, and vinblastine as well as combined treatment involving $2.77 \mu \mathrm{g} / \mathrm{mL}$ of $\delta$-tocotrienol and $0.35 \mu \mathrm{g} / \mathrm{mL}$ of jerantinine A for 24 hours. Cell cycle profiles show (b) representative flow cytometric images and (c, d) percentages of A549 cells in each phase. A549 cells were incubated with plain media containing DMSO (untreated control), $I C_{50}$ of $\delta$-tocotrienol, jerantinine $A$ and combined sub-effective concentrations of $\delta$-tocotrienol with $\mathrm{IC}_{20}$ of jerantinine $A$ for (c) 24 hours and (d) 48 hours. Single-compound $I C_{50}$ of $\delta$-tocotrienol and jerantinine $A$ induced G0/G1 and G2/M cell cycle arrests, respectively. The combined sub-effective concentrations of $\delta$-tocotrienol with $\mathrm{IC}_{20}$ of jerantinine $A$ induced $\mathrm{G} 2 / \mathrm{M}$ cell cycle arrest. $P<0.001\left(^{* * *}\right), P<0.01\left(^{* *}\right)$ and $P<0.05\left(^{*}\right)$ indicate a statistical significant difference between treated and untreated groups. Abbreviation: $\mathrm{h}=\operatorname{hour}(\mathrm{s})$.

On the other hand, tocotrienols have been shown to induce apoptosis via death receptor and mitochondria pathways, although the roles of caspase enzymes and caspase-independent apoptosis vary depending on the cellular microenvironment $(8,15)$. Herein, the individual doses of $\delta$-tocotrienol and jerantinine A induced caspase 8, 9 and 3 activities. In fact, an improved caspase 9 and 3 enzymatic activity was evident for the combined subeffective treatment compared to individual treatments. This suggests a potentially improved potency following the combined treatment. Death receptor and mitochondria pathways of apoptosis are mediated via caspase 8 and 9 enzymatic activities, respectively and both pathways can be linked at caspase 3 following the truncation of BID protein (12). The different patterns of cell cycle arrest and anti-microtubular effects induced by single-compound treatments of $\delta$-tocotrienol and jerantinine $\mathrm{A}$ as well as combined treatment strongly suggest that the combined treatment may be mediated via multi-targeted pathways. This conforms to a recent study that demonstrated the cytotoxic potency of combined low-concentration treatment of $\gamma$-tocotrienol and jerantinine A, which was also able to activate caspase 8,9 and 3 enzymatic activities and disrupt microtubules in a different cell type, i.e. brain cancer (6). This suggests that the combination of different isomers of tocotrienol such as $\gamma$ and $\delta$ with jerantinine derivatives might induce synergistic apoptotic effects against a broad spectrum of cancer cell lines. However, it is worthwhile to emphasize that the current combined $\delta$-tocotrienol and jerantinine $\mathrm{A}$ treatment induced 


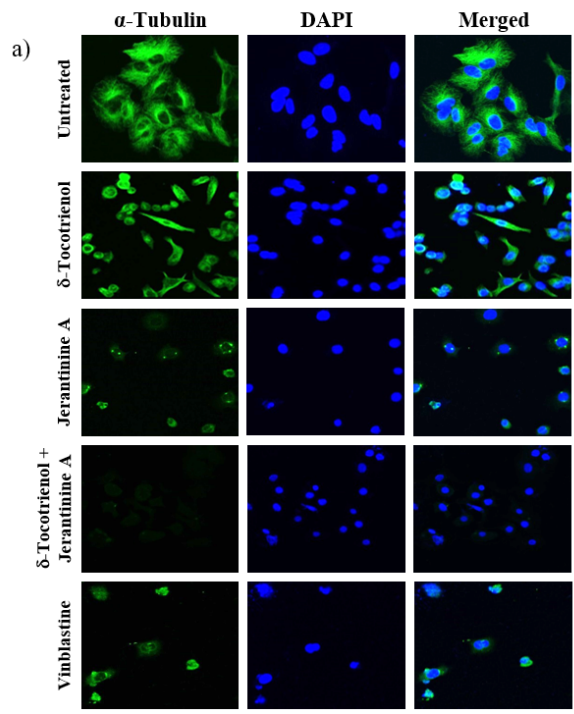

b)
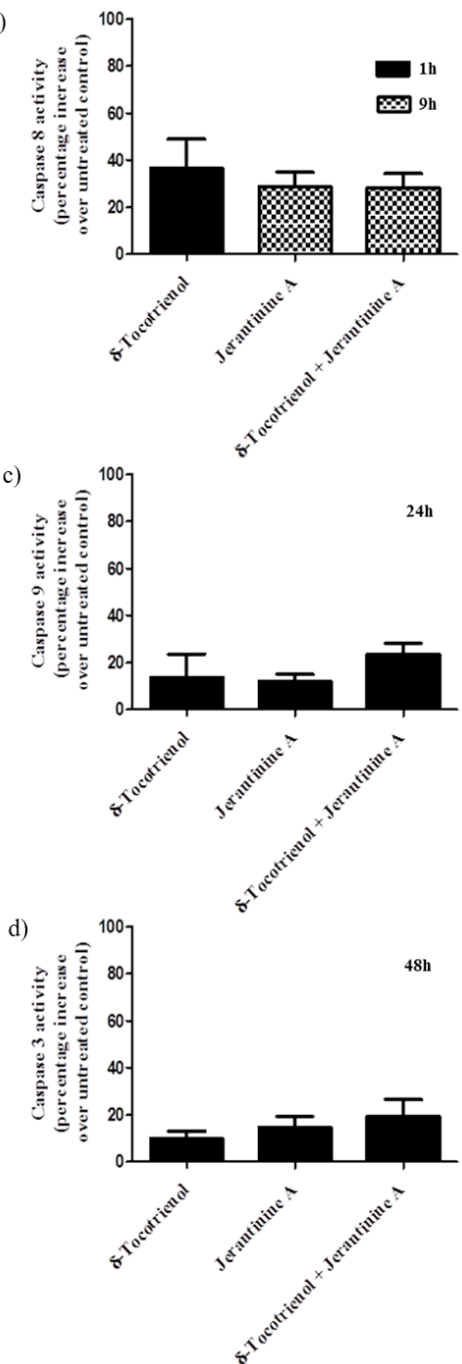

\begin{abstract}
Figure 2. Detection of microtubules and caspase enzymatic activity (reflected as percentage increase over untreated control) in A549 cells. (a) Representative of immunofluorescence microscopic images showing microtubules in A549 cells stained with anti- $\alpha$-tubulin antibody and counter-stained with goat anti-mouse IgG (FITC) and DAPI. A549 cells were incubated with plain media containing DMSO (untreated control), single-compound IC ${ }_{50}$ of vinblastine (positive control), $\delta$-tocotrienol, jerantinine $A$ and combined sub-effective concentrations of $\delta$-tocotrienol with $I C_{20}$ of jerantinine $A$ for 72 hours. Vinblastine, jerantinine $A$ and combined treatment but not $\delta$-tocotrienol caused a disruption of microtubular networks. Images were captured at $40 \mathrm{X}$ magnification under Nikon TI eclipse confocal microscope (Nikon, Japan). (b, c, d) Upregulation of caspase enzymatic activity in A549 cells induced by single-compound $\mathrm{IC}_{50}$ and combined sub-effective concentrations of $\delta$-tocotrienol and jerantinine $A$ on caspase 8 (b), caspase 9 (c) and caspase 3 (d). The result was reflected as mean \pm SD of percentage increase in caspase enzymatic activity of treatment groups over that of untreated control generated from triplicate experiments.
\end{abstract}

higher caspase 8 and 9 enzymatic activities in lung cancer cells than those observed in brain cancer cells treated by $\gamma$-tocotrienol and jerantinine A combination in the previous study (6). This even strengthens the speculation that the induction of apoptosis on A549 cells by current combined treatment is mediated via both death receptor and mitochondria pathways (12).

\section{Conclusion}

This study showed that the combined sub-effective concentrations of $\delta$-tocotrienol and jerantinine A caused inhibition of microtubular networks and activation of caspase enzymatic activities in addition to the established mechanism of action of $\delta$-tocotrienol. This demonstrates an improved potency of $\delta$-tocotrienol. Besides, the subeffective concentrations used in the combined treatment have minimized toxicity to MRC5 cells. Yet, this still necessitates more mechanistic and in vivo investigations in order to confirm the putative mechanisms of action and further develop the combined treatment against lung cancer.

\section{Acknowledgements}

The authors would like to thank Davos Life Science Pte Ltd, Singapore for providing $\delta$-tocotrienol isomer. 


\section{Authors' contributions}

IBA was involved in the experiment design, conducted the experiments and drafting of manuscript. HSL was involved in experimental design, manuscript corrections, proof reading and data analysis. All read and confirmed the final version of the manuscript.

\section{Conflict of interests}

The authors declare that there are no conflicts of interest.

\section{Ethical considerations}

All ethical issues have been checked by the authors and the study complies with ethical considerations.

\section{Funding/Support}

None.

\section{References}

1. Siegel RL, Miller KD, Jemal A. Cancer statistics, 2016. CA Cancer J Clin. 2016;66(1):7-30. doi: 10.3322/caac.21332.

2. Ju J, Picinich SC, Yang Z, Zhao Y, Suh N, Kong AN, et al. Cancer-preventive activities of tocopherols and tocotrienols. Carcinogenesis. 2010;31(4):533-42. doi: 10.1093/carcin/bgp205.

3. Shirode AB, Sylvester PW. Synergistic anticancer effects of combined gamma-tocotrienol and celecoxib treatment are associated with suppression in Akt and NFkappaB signaling. Biomed Pharmacother. 2010;64(5):327-32. doi: 10.1016/j.biopha.2009.09.018.

4. Abubakar IB, Loh HS. A review on ethnobotany, pharmacology and phytochemistry of Tabernaemontana corymbosa. J Pharm Pharmacol. 2016;68(4):423-32. doi: 10.1111/jphp.12523.

5. Raja VJ, Lim KH, Leong CO, Kam TS, Bradshaw TD. Novel antitumour indole alkaloid, Jerantinine A, evokes potent G2/M cell cycle arrest targeting microtubules. Invest New Drugs. 2014;32(5):838-50. doi: 10.1007/s10637-014-01261 .

6. Abubakar IB, Lim KH, Kam TS, Loh HS. Enhancement of apoptotic activities on brain cancer cells via the combination of gamma-tocotrienol and jerantinine A. Phytomedicine. 2017;30:74-84. doi: 10.1016/j.phymed.2017.03.004.

7. Lim SW, Ting KN, Bradshaw TD, Zeenathul NA, Wiart C, Khoo TJ, et al. Acalypha wilkesiana extracts induce apoptosis by causing single strand and double strand DNA breaks. J Ethnopharmacol. 2011;138(2):616-23. doi: 10.1016/j.jep.2011.10.005.

8. Lim SW, Loh HS, Ting KN, Bradshaw TD, Zeenathul NA. Antiproliferation and induction of caspase-8dependent mitochondria-mediated apoptosis by betatocotrienol in human lung and brain cancer cell lines. Biomed Pharmacother. 2014;68(8):1105-15. doi: 10.1016/j. biopha.2014.10.006.

9. Abubakar IB, Lim KH, Loh HS. Alkaloid extracts of Ficus species and palm oil-derived tocotrienols synergistically inhibit proliferation of human cancer cells. Nat Prod Res. 2015;29(22):2137-40. doi: 10.1080/14786419.2014.991927.

10. Wali VB, Sylvester PW. Synergistic antiproliferative effects of gamma-tocotrienol and statin treatment on mammary tumor cells. Lipids. 2007;42(12):1113-23. doi: 10.1007/ s11745-007-3102-0.

11. Abubakar IB, Lim KH, Kam TS, Loh HS. Synergistic cytotoxic effects of combined delta-tocotrienol and jerantinine B on human brain and colon cancers. J Ethnopharmacol. 2016;184:107-18. doi: 10.1016/j.jep.2016.03.004.

12. Elmore S. Apoptosis: a review of programmed cell death. Toxicol Pathol. 2007;35(4):495-516. doi: $10.1080 / 01926230701320337$.

13. Bhalla KN. Microtubule-targeted anticancer agents and apoptosis. Oncogene. 2003;22(56):9075-86. doi: 10.1038/ sj.onc. 1207233.

14. Broker LE, Huisman C, Span SW, Rodriguez JA, Kruyt FA, Giaccone G. Cathepsin B mediates caspase-independent cell death induced by microtubule stabilizing agents in nonsmall cell lung cancer cells. Cancer Res. 2004;64(1):27-30.

15. Constantinou C, Papas A, Constantinou AI. Vitamin E and cancer: An insight into the anticancer activities of vitamin $\mathrm{E}$ isomers and analogs. Int J Cancer. 2008;123(4):739-52. doi: 10.1002/ijc.23689. 